\title{
ANALISIS VALIDITAS BAHAN AJAR STRUKTUR ALJABAR BERBASIS STRATEGI ABDUKTIF-DEDUKTIF
}

\author{
Hamidah Suryani Lukman', Yanti Mulyanti ${ }^{2}$ \\ ${ }^{1}$ Universitas Muhammadiyah Sukabumi, Jl. R. Syamsudin, S.H No 50 Sukabumi, \\ hamni_alkhawarizmi@yahoo.co.id \\ ${ }^{2}$ Universitas Muhammadiyah Sukabumi, Jl. R. Syamsudin, S.H No 50 Sukabumi, \\ yanti_khairan@yahoo.co.id
}

\begin{abstract}
ABSTRAK
Artikel ini berisi tentang analisis validitas bahan ajar struktur aljabar berbasis strategi abduktif deduktif yang merupakan salah satu bagian dari penelitian pengembangan (research and development) tahap pertama, yaitu expert judgement. Intrumen yang digunakan pada penelitian ini adalah lembar validasi yang terdiri dari 5 aspek penilaian, yaitu kelayakan aspek materi, kelayakan aspek kebahasaan, kelayakan aspek penyajian, kelayakan efek bahan ajar terhadap proses belajar mahasiswa, dan kelayakan aspek tampilan keseluruhan. Validator yang terlibat dalam penelitian ini adalah 4 orang ahli di bidang pendidikan matematika. Data hasil penelitian ini dianalisis secara deskriptif. Adapun hasil penelitian menunjukkan bahwa 80\% kriteria kelayakan aspek materi sudah terpenuhi tergolong kategori sangat baik $(4,21)$, 90\% kriteria kelayakan aspek kebahasaan sudah terpenuhi dan tergolong kategori sangat baik $(4,81), 85 \%$ kriteria kelayakan aspek penyajian sudah terpenuhi dan tergolong kategori sangat baik $(4,50), 80 \%$ kriteria kelayakan efek bahan ajar terhadap proses belajar mahasiswa sudah terpenuhi tergolong kategori sangat baik $(4,25)$, serta $80 \%$ kriteria kelayakan aspek tampilan keseluruhan sudah terpenuhi dan tergolong kategori sangat baik $(4,25)$. Berdasarkan data tersebut, $85 \%$ kriteria penilaian kelayakan bahan ajar struktur aljabar berbasis strategi abduktifdeduktif yang dikembangkan secara keseluruhan sudah terpenuhi dan tergolong kategori sangat baik $(4,35)$ serta layak digunakan dalam pembelajaran.
\end{abstract}

Kata kunci: Validitas, Bahan Ajar, Struktur Aljabar.

\section{ABSTRACT}

This paper explains about the analysis of validity of abstract algebra teaching materials based on abductive-deductive strategy which is the first stage on research and development study, expert judgement. The instrument used in this research is validation sheet consisting of five aspects of the assessment, namely the feasibility of the material aspect, the feasibility of the language aspect, the feasibility of the presentation aspect, the feasibility of teaching effect on the student learning process, and the feasibility of the overall display aspect. Validator involved in this research is four experts in mathematics education. The data of this research are analyzed descriptively. The result of this research shows that $80 \%$ of eligibility criteria of the material aspect have been fulfilled are categorized as very good (4.21), $90 \%$ of language aspect eligibility criteria have been fulfilled and categorized excellent (4.81), 85\% of the presentation aspect eligibility criteria have been fulfilled and categorized as very good (4.50), 80\% of the criteria for the effect of teaching materials on the students' learning process have been fulfilled as very good category (4.25), and $80 \%$ of eligibility criteria of the overall display aspect have been fulfilled and categorized as very good (4.25). Based on these data, $85 \%$ of the criteria for the assessment of the feasibility of Abstract algebra teaching materials based on the abductive-deductive strategy have been fulfilled, categorized as very good (4.35), and suitable for use in learning.

Keywords: Validity, Teaching Materials, Abstract Algebra. 
How to Cite: Lukman, H. S., \& Yanti, M. (2017). Analisis Validtas Bahan Ajar Struktur Aljabar Berbasis Strategi Abduktif-deduktif. Mathline: Jurnal Matematika dan Pendidikan Matematika, Vol.2, No.2, 159-166.

\section{PENDAHULUAN}

Struktur Aljabar merupakan mata kuliah yang sarat dengan definisi dan teorema di dalam matematika (Arnawa, 2009). Mata kuliah ini tidak mempelajari perhitungan, namun lebih banyak mengkonstruksi dan memvalidasi pembuktian suatu argumen atau konsep matematika. Sehingga, dengan mempelajari mata kuliah ini, mahasiswa mampu berpikir rasional, logis, dan sistematis, serta mampu menganalisis validitas suatu argumen.

Namun, membelajarkan mahasiswa untuk membaca maupun mengkonstruksi pembuktian secara matematis tidak semudah yang dipikirkan. Beberapa penelitian mengemukakan bahwa pembuktian matematis merupakan kemampuan yang sulit bagi siswa SMA maupun mahasiswa (Maya \& Sumarmo, 2011). Moore (Maya \& Sumarmo, 2011) mengkategorikan kesulitan kemampuan pembuktian ini ke dalam tujuh alasan, diantaranya: 1) ketidaktahuan mahasiswa tentang definisi; 2) mahasiswa hanya memiliki pemahaman intuitif dalam konsep matematika; 3) pemahaman konsep mahasiswa belum cukup untuk melakukan pembuktian; 4) mahasiswa tidak mampu mengeneralisasi maupun menggunakan contoh yang dimilikinya; 5) mahasiswa tidak tahu bagaimana menggunakan definisi untuk memperoleh bukti terstruktur; 6) mahasiswa tidak mampu memahami dan menggunakan bahasa matematis serta simbol-simbolnya; dan 7) mahasiswa tidak tahu bagaimana memulai pembuktian.

Sejalan dengan pendapat tersebut, sulitnya menumbuhkembangkan kemampuan pembuktian dapat dilihat pada mata kuliah Struktur Aljabar. Fakta di lapangan menunjukkan bahwa kemampuan pembuktian mahasiswa dalam mata kuliah Struktur Aljabar masih rendah. Berdasarkan pengalaman dan sekaligus observasi dalam mengampu mata kuliah Struktur Aljabar, nilai akhir yang diperoleh mahasiswa pada tahun akademik 2015/2016 yang terdiri dari 17 mahasiswa, hanya 20\% memperoleh nilai memuaskan dan mencapai kriteria ketuntasan, 38\% mahasiswa memperoleh nilai di atas rata-rata namun belum begitu memuaskan, sedangkan $42 \%$ mahasiswa memperoleh nilai di bawah ratarata.

Oleh karena itu, diperlukan suatu inovasi pembelajaran yang diharapkan dapat membuat mahasiswa belajar bermakna, sehingga kemampuan pembuktian matematis dapat dilatih dan ditumbuhkembangkan. Salah satu inovasi pembelajaran tersebut dapat 
diwujudkan melalui pengembangan bahan ajar yang dirancang khusus untuk menumbuhkembangkan kemampuan pembuktian matematis mahasiswa dalam mata kuliah Struktur Aljabar. Adapun bahan ajar yang dikembangkan adalah bahan ajar yang berbasis strategi Abduktif-Deduktif. Hal ini dikarenakan beberapa hasil penelitian seperti yang dilakukan Kusnandi (2008) serta Hiltrimartin \& Hartono (Kusnandi, 2008), menunjukkan bahwa pembelajaran dengan strategi Abduktif-Deduktif dapat menumbuhkembangkan kemampuan membuktikan mahasiswa dalam mata kuliah analisis, seperti Teori Bilangan dan Struktur Aljabar.

Strategi Abduktif-Deduktif dikembangkan oleh Kusnandi (2008), secara khusus dirancang untuk memunculkan gagasan utama dari struktur pembuktian, baik untuk memahami pembuktian yang ada maupun untuk mengkonstruksi pembuktian. Sehingga, penulis menduga bahwa bahan ajar Struktur Aljabar yang dikembangkan menggunakan strategi Abduktif-Deduktif, dapat menumbuhkembangkan kemampuan pembuktian matematis mahasiswa.

Berdasarkan uraian-uraian tersebut, maka studi yang berfokus pada pengembangan bahan ajar untuk meningkatkan kemampuan pembuktian matematis mahasiswa perlu dilakukan. Oleh karena itu, penelitian ini merupakan penelitian pengembangan mengenai bahan ajar struktur aljabar berbasis srategi abduktif-deduktif. Pengembangan bahan ajar pada prinsipnya memiliki tiga kriteria utama, yaitu valid, praktis, dan efektif. Namun pada artikel ini pembahasan difokuskan pada kriteria valid, sehingga tujuan penelitian ini adalah untuk mengetahui validitas bahan ajar struktur aljabar berbasis strategi abduktif-deduktif yang dikembangkan.

\section{METODE PENELITIAN}

Metode penelitan yang digunakan adalah penelitian dan pengembangan Borg dan Gall (Trisnaningsih, 2007) yang mencakup 5 tahapan, yaitu: 1) melakukan analisis produk yang akan dikembangkan; 2) mengembangkan produk awal; 3) validasi ahli dan revisi; 4) uji coba lapangan skala kecil dan revisi produk; dan 5) uji coba lapangan skala besar dan produk akhir. Namun, pada artikel ini metode yang digunakan merupakan tahap pertama yaitu mengembangkan produk awal berupa bahan ajar struktur aljabar berbasis strategi abduktif-deduktif dan validasi ahli.

Validasi ini dilakukan oleh tim validator yang terdiri dari 4 orang dosen ahli di bidang Pendidikan Matematika. Teknik validasi yang digunakan adalah teknik Delphi, yaitu penilaian yang dilakukan oleh sekelompok ahli secara kontinu melalui kuesioner 
untuk memudahkan pembentukan suatu keputusan kelompok, tanpa perlu seluruhnya bertatap muka.

Instrumen yang digunakan adalah kuesioner yang berupa lembar validasi bahan ajar yang terdiri dari lima aspek penilaian dan 23 indikator. Kelima aspek penilaian tersebut, diantaranya penilaian kelayakan aspek materi, kelayakan aspek kebahasaan, kelayakan aspek penyajian, kelayakan efek bahan ajar terhadap proses belajar mahasiswa, dan kelayakan aspek tampilan keseluruhan. Selanjutnya, data yang diperoleh dianalisis secara deskriptif.

\section{HASIL DAN PEMBAHASAN}

Penilaian validitas bahan ajar struktur aljabar berbasis strategi abduktif-deduktif oleh tim ahli mencakup empat bahasan materi, yaitu 1) grup; 2) subgrup dan teorema pada grup; 3) koset dan subgrup normal; serta 4) homomorfisma grup. Proses validasi ini dilakukan oleh tiga orang dosen Pendidikan Matematika Universitas Muhammadiyah Sukabumi dan satu orang Dosen STKIP Garut. Adapun aspek yang dinilai mencakup penilaian kelayakan aspek materi (12 indikator), kelayakan aspek kebahasaan (4 indikator), kelayakan aspek penyajian (2 indikator), kelayakan efek bahan ajar terhadap proses belajar mahasiswa (3 indikator), dan kelayakan aspek tampilan keseluruhan (2 indikator).

Keseluruhan penilaian validitas dinilai menggunakan skala 1-5, dengan kategori diantaranya 1 (Tidak baik), 2 (Kurang baik), 3 (Cukup baik), 4 (Baik), dan 5 (Sangat baik). Untuk memperjelas penilaian, maka skala 1-5 selanjutnya diberikan kriteria sebagai berikut, yaitu skala 1 jika kriteria yang terpenuhi kurang dari 20\%; skala 2 jika 20\%-39\% kriteria telah terpenuhi; skala 3 jika 40\%-59\% kriteria telah terpenuhi; skala 4 jika 60\%$79 \%$ kriteria telah terpenuhi; dan skala 5 jika 80-100\% kriteria telah terpenuhi.

Berdasarkan hasil validasi tim ahli, aspek kelayakan materi memiliki nilai 202 dari total skor 240 atau memperoleh rata-rata penilaian validator sebesar 4,21 dari skala 5. Ini berarti $80 \%$ materi yang digunakan dalam bahan ajar struktur aljabar berbasis strategi abduktif-deduktif sudah layak digunakan. Dengan kata lain, kesesuaian dan kelayakan materi yang digunakan dalam bahan ajar ini tergolong kategori sangat baik. Penilaian masing-masing indikator dari aspek kelayakan materi disajikan pada tabel berikut. 
Tabel 1 Penilaian Per-Indikator dari Kelayakan Aspek Materi

\begin{tabular}{|c|c|c|c|c|}
\hline No & Indikator dan deskripsinya & $\begin{array}{l}\text { Rata-rata } \\
\text { Penilaian } \\
\text { Validator }\end{array}$ & Keterangan & Kesimpulan \\
\hline 1 & $\begin{array}{l}\text { Kesesuaian isi materi dengan } \\
\text { Capaian Pembelajaran dan } \\
\text { Capaian Pendukung/indikator }\end{array}$ & 4,75 & $\begin{array}{l}\text { 80-100\% kriteria } \\
\text { telah terpenuhi }\end{array}$ & Sangat baik \\
\hline 2 & $\begin{array}{l}\text { Konsep dan definisi disajikan } \\
\text { sesuai dengan konsep dan } \\
\text { definisi yang berlaku dalam } \\
\text { bidang ilmu matematika }\end{array}$ & 4,75 & $\begin{array}{l}80-100 \% \text { kriteria } \\
\text { telah terpenuhi }\end{array}$ & Sangat baik \\
\hline 3 & $\begin{array}{l}\text { Materi yang dibahas dapat } \\
\text { dimengerti dengan jelas }\end{array}$ & 4,50 & $\begin{array}{l}80-100 \% \text { kriteria } \\
\text { telah terpenuhi }\end{array}$ & Sangat baik \\
\hline 4 & $\begin{array}{l}\text { Materi dibahas secara runut dan } \\
\text { sistematis }\end{array}$ & 5,00 & $\begin{array}{l}80-100 \% \text { kriteria } \\
\text { telah terpenuhi }\end{array}$ & Sangat baik \\
\hline 5 & $\begin{array}{l}\text { Materi yang disajikan tercakup } \\
\text { dalam keseluruhan bahan ajar }\end{array}$ & 4,50 & $\begin{array}{l}80-100 \% \text { kriteria } \\
\text { telah terpenuhi }\end{array}$ & Sangat baik \\
\hline 6 & $\begin{array}{l}\text { Materi yang disajikan dibahas } \\
\text { secara tuntas }\end{array}$ & 3,75 & $\begin{array}{l}60 \%-79 \% \text { kriteria } \\
\text { telah terpenuhi }\end{array}$ & Baik \\
\hline 7 & $\begin{array}{l}\text { Tingkat } \begin{array}{r}\text { kesulitan } \\
\text { keabstrakan konsep }\end{array} \text { sesuai } \\
\text { dengan tingkatan berfikir } \\
\text { mahasiswa, sehingga mahasiswa } \\
\text { mudah mencerna materi dalam } \\
\text { bahan ajar }\end{array}$ & 4,50 & $\begin{array}{l}80-100 \% \text { kriteria } \\
\text { telah terpenuhi }\end{array}$ & Sangat baik \\
\hline 8 & $\begin{array}{l}\text { Contoh yang disajikan sesuai } \\
\text { dan terkait dengan kondisi yang } \\
\text { ada }\end{array}$ & 2,75 & $\begin{array}{l}40 \%-59 \% \text { kriteria } \\
\text { telah terpenuhi }\end{array}$ & Cukup baik \\
\hline 9 & $\begin{array}{l}\text { Contoh disajikan dengan jelas } \\
\text { dan mendukung pemahaman } \\
\text { mahasiswa }\end{array}$ & 3,00 & $\begin{array}{l}40 \%-59 \% \text { kriteria } \\
\text { telah terpenuhi }\end{array}$ & Cukup baik \\
\hline 10 & $\begin{array}{l}\text { Materi dan contoh yang } \\
\text { disajikan mendukung } \\
\text { kemandirian belajar mahasiswa }\end{array}$ & 4,00 & $\begin{array}{l}60 \%-79 \% \text { kriteria } \\
\text { telah terpenuhi }\end{array}$ & Baik \\
\hline 11 & $\begin{array}{l}\text { Evaluasi yang diberikan sesuai } \\
\text { dengan materi dan tujuan } \\
\text { pembelajaran }\end{array}$ & 4,75 & $\begin{array}{l}80-100 \% \text { kriteria } \\
\text { telah terpenuhi }\end{array}$ & Sangat Baik \\
\hline 12 & $\begin{array}{l}\text { Aspek pembelajaran kognitif } \\
\text { mulai dari mengingat sampai } \\
\text { pada tahapan megevaluasi telah } \\
\text { terintegrasi dalam bahan ajar. }\end{array}$ & 4,25 & $\begin{array}{l}80-100 \% \text { kriteria } \\
\text { telah terpenuhi }\end{array}$ & Sangat Baik \\
\hline
\end{tabular}

Berdasarkan tabel tersebut, beberapa revisi yang dilakukan adalah memperbaiki pembuktian teorema pada beberapa materi yang disajikan sesuai dengan tahapan abduktifdeduktif serta menambahkan ilustrasi dan contoh pada beberapa kasus pembuktian, supaya mahasiswa lebih memahami alur bukti yang disajikan dalam bahan ajar dan mampu membaca pembuktian tersebut dengan baik dan benar.

Aspek kelayakan penggunaan bahasa memiliki nilai 77 dari skor total 80 atau memperoleh rata-rata penilaian validator sebesar 4,81 dari skala 5 . Ini berarti $90 \%$ bahasa 
yang digunakan dalam bahan ajar struktur aljabar berbasis strategi abduktif-deduktif sudah sesuai dengan kaidah Bahasa Indonesia yang baik dan benar. Dengan kata lain, kesesuaian dan kelayakan penggunaan bahasa yang digunakan dalam bahan ajar ini tergolong kategori sangat baik. Penilaian masing-masing indikator dari aspek kelayakan penggunaan bahasa disajikan pada tabel berikut.

Tabel 2. Penilaian Per-Indikator dari Kelayakan Aspek Penggunaan Bahasa

\begin{tabular}{|c|c|c|c|c|}
\hline No & Indikator dan deskripsinya & $\begin{array}{l}\text { Rata-rata } \\
\text { Penilaian } \\
\text { Validator }\end{array}$ & Keterangan & Kesimpulan \\
\hline 1 & $\begin{array}{l}\text { Petunjuk penggunaan bahan ajar } \\
\text { disampaikan dengan jelas }\end{array}$ & 4,75 & $\begin{array}{l}80-100 \% \text { kriteria } \\
\text { telah terpenuhi }\end{array}$ & Sangat baik \\
\hline 2 & $\begin{array}{l}\text { Istilah-istilah yang digunakan } \\
\text { tepat dan sesuai dengan bidang } \\
\text { ilmu matematika }\end{array}$ & 4,75 & $\begin{array}{l}\text { 80-100\% kriteria } \\
\text { telah terpenuhi }\end{array}$ & Sangat baik \\
\hline 3 & $\begin{array}{l}\text { Penggunaan bahasa mendukung } \\
\text { kemudahan memahami alur } \\
\text { materi }\end{array}$ & 4,75 & $\begin{array}{l}80-100 \% \text { kriteria } \\
\text { telah terpenuhi }\end{array}$ & Sangat baik \\
\hline 4 & $\begin{array}{l}\text { Penggunaan bahasa tetap santun } \\
\text { dan tidak mengurangi nilai-nilai } \\
\text { pendidikan }\end{array}$ & 5,00 & $\begin{array}{l}80-100 \% \text { kriteria } \\
\text { telah terpenuhi }\end{array}$ & Sangat baik \\
\hline
\end{tabular}

Aspek kelayakan penyajian bahan ajar memiliki nilai 36 dari skor total 40 atau memperoleh rata-rata penilaian validator sebesar 4,50 dari skala 5. Ini berarti $85 \%$ bahan ajar struktur aljabar berbasis strategi abduktif-deduktif disajikan dengan baik. Dengan kata lain, penyajian bahan ajar ini tergolong kategori sangat baik. Penilaian masing-masing indikator dari aspek kelayakan penyajian bahan ajar disajikan pada tabel berikut.

Tabel 3. Penilaian Per-Indikator dari Kelayakan Penyajian Bahan Ajar

\begin{tabular}{clccc}
\hline No & Indikator dan deskripsinya & $\begin{array}{l}\text { Rata-rata } \\
\text { Penilaian } \\
\text { Validator }\end{array}$ & Keterangan & Kesimpulan \\
\hline 1 & $\begin{array}{l}\text { Penyajian ilustrasi gambar } \\
\text { selaras dengan teks yang } \\
\text { disajikan dalam bahan ajar }\end{array}$ & 4,50 & $\begin{array}{l}80-100 \% \text { kriteria } \\
\text { telah terpenuhi }\end{array}$ & Sangat baik \\
2 & $\begin{array}{l}\text { Alur materi yang disajikan } \\
\text { setiap bab jelas dan sesuai }\end{array}$ & 4,50 & $\begin{array}{l}80-100 \% \text { kriteria } \\
\text { telah terpenuhi }\end{array}$ & Sangat baik \\
\hline
\end{tabular}

Aspek efektivitas bahan ajar terhadap proses belajar mengajar memiliki nilai 51 dari skor total 60 atau memperoleh rata-rata penilaian validator sebesar 4,25 dari skala 5. Ini berarti lebih dari $80 \%$ bahan ajar struktur aljabar berbasis strategi abduktif-deduktif efektif digunakan dalam proses belajar mengajar. Dengan kata lain, efektivitas bahan ajar tersebut terhadap proses belajar mengajar tergolong kategori sangat baik. Penilaian masing-masing indikator dari aspek efektivitas bahan ajar terhadap proses belajar mengajar disajikan pada tabel berikut. 
Tabel 4. Penilaian Per-Indikator dari Aspek Efektivitas Bahan Ajar Terhadap Proses Belajar Mengajar

\begin{tabular}{clccc}
\hline No & Indikator dan deskripsinya & $\begin{array}{l}\text { Rata-rata } \\
\text { Penilaian } \\
\text { Validator }\end{array}$ & Keterangan & Kesimpulan \\
\hline 1 & $\begin{array}{l}\text { Bahan ajar mudah untuk } \\
\text { digunakan dalam proses } \\
\text { pembelajaran, baik secara } \\
\text { mandiri maupun di dalam }\end{array}$ & 4,00 & $\begin{array}{c}60 \%-79 \% \text { kriteria } \\
\text { telah terpenuhi }\end{array}$ & Baik \\
$\begin{array}{l}\text { perkuliahan } \\
\text { Bahan ajar mendukung } \\
\text { mahasiswa untuk dapat belajar } \\
\text { secara mandiri }\end{array}$ & 4,00 & $\begin{array}{l}60 \%-79 \% \text { kriteria } \\
\text { telah terpenuhi }\end{array}$ & Baik \\
Bahan ajar dapat menambah \\
pengetahuan bagi mahasiswa
\end{tabular}

Berdasarkan tabel tersebut, beberapa revisi yang dilakukan adalah memperjelas tahapan pembuktian pada materi yang disajikan, disesuaikan dengan tahapan abduktifdeduktif pada lembar kerja mahasiswa, sehingga diharapkan mahasiswa mampu belajar mandiri khususnya dlam mengkonstruksi pembuktian.

Aspek kelayakan tampilan bahan ajar memiliki nilai 34 dari skor total 40 atau memperoleh rata-rata penilaian validator sebesar 4,25 dari skala 5. Ini berarti bahan ajar struktur aljabar berbasis strategi abduktif-deduktif, 80\% memiliki tampilan yang baik dan menarik. Dengan kata lain, tampilan bahan ajar ini tergolong kategori sangat baik. Penilaian masing-masing indikator dari aspek kelayakan tampilan bahan ajar disajikan pada tabel berikut.

Tabel 5. Penilaian Per-Indikator dari Kelayakan Tampilan Bahan Ajar

\begin{tabular}{ccccc}
\hline No & Indikator dan deskripsinya & $\begin{array}{l}\text { Rata-rata } \\
\text { Penilaian } \\
\text { Validator }\end{array}$ & Keterangan & Kesimpulan \\
\hline 1 & $\begin{array}{l}\text { Cakupan judul sudah mewakili } \\
\text { keseluruhan materi yang } \\
\text { disajikan }\end{array}$ & 3,75 & $\begin{array}{c}60 \%-79 \% \text { kriteria } \\
\text { telah terpenuhi }\end{array}$ & Baik \\
2 & $\begin{array}{l}\text { Teks/ tulisan yang disajikan } \\
\text { mudah dibaca oleh mahasiswa }\end{array}$ & 4,75 & $\begin{array}{l}80-100 \% \text { kriteria } \\
\text { telah terpenuhi }\end{array}$ & Sangat baik \\
\hline
\end{tabular}

Penilaian secara keseluruhan bahan ajar struktur aljabar berbasis strategi abduktifdeduktif memiliki nilai 400 dari skor total 460 atau memperoleh rata-rata penilaian validator sebesar 4,35 dari skala 5. Ini berarti lebih $80 \%$ bahan ajar struktur aljabar berbasis strategi abduktif-deduktif sudah layak digunakan dalam pembelajaran.

Meskipun sudah tergolong sangat baik, namun sebagai penyempurnaan tampilan bahan ajar, terdapat beberapa hal yang direvisi, diantaranya penambahan ukuran kotak untuk merumuskan strategi abduktif-deduktif; menambahkan beberapa materi prasyarat yang diperlukan dan sering digunakan; menambahkan ilustrasi penjelasan menenai simbol- 
simbol yang digunakan; menambahkan contoh pembuktian matematis yang menggunakan strategi abduktif-deduktif bukan hanya di lembar kerja, melainkan dalam pembuktian beberapa materi; serta merevisi beberapa pembuktian yang kurang jelas tahapannya.

\section{KESIMPULAN}

Berdasarkan rumusan masalah dan analisis data pada penilaian validitas bahan ajar struktur aljabar berbasis strategi abduktif-deduktif yang dikembangkan, diperoleh bahwa 80\% kriteria kelayakan aspek materi sudah terpenuhi dan tergolong kategori sangat baik $(4,21)$. Pada kelayakan aspek kebahasaan, 90\% kriteria penilaian sudah terpenuhi dan tergolong kategori sangat baik $(4,81)$. Pada kelayakan aspek penyajian, $85 \%$ kriteria sudah terpenuhi dan tergolong kategori sangat baik $(4,50)$. Pada kelayakan efek bahan ajar terhadap proses belajar mahasiswa, $80 \%$ kriteria sudah terpenuhi tergolong kategori sangat baik (4,25). Pada kelayakan aspek tampilan keseluruhan, serta $80 \%$ kriteria sudah terpenuhi dan tergolong kategori sangat baik $(4,25)$. Berdasarkan data tersebut, $85 \%$ kriteria penilaian kelayakan bahan ajar struktur aljabar berbasis strategi abduktif-deduktif yang dikembangkan secara keseluruhan sudah terpenuhi dan tergolong kategori sangat baik $(4,35)$ serta valid dan layak digunakan dalam pembelajaran.

\section{UCAPAN TERIMA KASIH}

Penelitian ini didanai oleh DRPM Kemenristek DIKTI pada skim Penelitian Dosen Pemula tahun anggaran 2017. Oleh karena itu penulis mengucapkan terima kasih yang sebesar-besarnya atas bantuan tersebut sehingga penelitian ini dapat terlaksana dengan baik dan dapat diselesaikan tepat waktu.

\section{DAFTAR PUSTAKA}

Arnawa, I. M. (2009). Meningkatkan Kemampuan Pembuktian Mahasiswa dalam Aljabar Abstrak melalui Pembelajaran berdasarkan Teori APOS. [Online] tersedia dalam http://journal.fmipa.itb.ac.id/jms/article/view/238/248 [20 Maret 2016].

Kusnandi. (2008). Pembelajaran Matematika dengan Strategi Abduktif-Deduktif untuk Menumbuhkembangkan Kemampuan Membuktikan pada Mahasiswa. Bandung: Disertasi Universitas Pendidikan Indonesia.

Maya, R. \& Sumarmo, U. (2011). Mathematical Understanding and Proving Abilities: Eperiment with Undergraduate Student by using Modified Moore Learning Approach. Kumpulan Makalah Berpikir dan Disposisi Matematik serta Pembelajarannya. Bandung: Jurusan Pendidikan Matematika UPI

Sugiyono. (2011). Metode Penelitian Pendidikan: Pendekatan Kuantitatif, Kualitatif, dan $R \& D$. Bandung: Alfabeta.

Trisnaningsih. (2007). Pengembangan Bahan Ajar untuk Meningkatkan Pemahaman Materi Mata Kuliah Demografi Teknik. Jurnal Ekonomi dan Pendidikan. 4 (2), 1-13. 